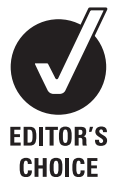

CHOICE

\title{
The case for OFSMOKE: how tobacco price regulation is needed to promote the health of markets, government revenue and the public
}

\author{
Anna B Gilmore, ${ }^{1,2,3}$ J Robert Branston, ${ }^{4}$ David Sweanor ${ }^{5}$
}

${ }^{1}$ School for Health, University of Bath, Bath, UK

${ }^{2} U K$ Centre for Tobacco Control

Studies, UK

${ }^{3}$ London School of Hygiene and

Tropical Medicine, UK

${ }^{4}$ Centre for Governance and

Regulation, School of

Management, University of

Bath, Bath, UK

${ }^{5}$ Faculty of Law, University of

Ottawa, Ottawa, Ontario,

Canada

Correspondence to

Dr Anna Gilmore, Department

for Health, University of Bath,

Claverton Down, Bath BA2 7AY,

UK; a.gilmore@bath.ac.uk

Received 20 October 2009

Accepted 9 July 2010

\section{ABSTRACT}

Mainstream economic theory outlines four main causes of market failure and it is already well established that two of these (information failure and externalities) exist in a tobacco market. A third cause of market failure, market power, is also a serious problem in many tobacco markets. Market power - combined with unintended and often overlooked consequences of tobacco tax policies, notably that gradual increases in specific taxes may allow the industry to disguise significant price increases - has, at least in high income countries, given cigarette manufacturers considerable pricing power and profits. This paper examines ways this market failure could be addressed and proposes as a solution a system of price cap regulation wherein a cap is placed on the pre-tax cigarette manufacturers' price but not on the retail price that consumers face. Well established in the utilities industry, price cap regulation would set a maximum price that cigarette companies can charge for their product based on an assessment of the genuine costs each firm faces in its operations and an assumption about the efficiency savings it would be expected to make. Such a system would achieve three main benefits. First, it would address the problem of market failure and excess profits while simultaneously allowing current tobacco control policies, including tax and price increases, to expand-thus tax increases would remain a central tenet of tobacco control policies and retail prices could continue to increase. Second, it would increase government revenue by transferring the excess profits from the industry to the government purse. Third, it would bring numerous public health benefits. In addition to addressing market power, while simultaneously allowing tobacco control policies to expand, it could offer a means of preventing downtrading to cheaper products and controlling unwanted industry practices such as cigarette smuggling, price fixing and marketing to the young. The paper outlines in some detail how such a system might be developed in the UK, while briefly exploring how it could be applied elsewhere, including in markets with state monopolies.

\section{INTRODUCTION}

This paper makes a radical proposal for the regulation of tobacco markets which are overwhelmingly dominated by cigarettes. It shows how market failure, in the form of market power, combined with well intentioned and necessary tobacco control policies, including taxation and marketing restrictions, have had the unintended consequence of giving cigarette manufacturers considerable pricing power and profits. In so doing, it outlines an overlooked issue in tobacco control: gradual increases in specific taxes benefit cigarette manufacturers by enabling them to increase prices and thus profits, an issue which explains why industry profits continue to increase despite falling cigarette sales. It then explores ways of addressing this problem, proposing as a solution a system of price cap regulation which, by capping cigarette manufacturers' prices but not the price that consumers face at retail outlets, would allow governments to maintain and expand their tobacco control policies while mitigating their unintended consequences. In other words, this proposal would allow tax increases to remain a central tenet of tobacco control policy, but would do so while simultaneously preventing the high manufacturer profits and market distortions.

To explore how this might work in practice this paper uses the UK as an example, outlining how such an approach would not only address market failure and capture the rent currently accruing to the tobacco industry for the public purse, but also bring numerous public health advantages. Finally, the paper suggests that such a system could be applied to most markets, including those with state monopolies, by adapting it as necessary to the national context.

\section{PROBLEMS WITH THE CURRENT TOBACCO MARKET AND THE TOBACCO PRICING SYSTEM Market failure}

Mainstream economic theory outlines four main causes of market failure: information failure or asymmetry, externalities such as the external costs imposed on others through the manufacture and use of tobacco, the provision of public goods and market power. ${ }^{1}$ That two of these (information failure and externalities) exist in a tobacco market has already been clearly outlined ${ }^{2}$ and is not dwelt on further here. Instead, we outline how market power also exists.

The number of major tobacco transnationals has been declining following numerous mergers and acquisitions such that there are now only four dominating the global tobacco market outside China: Philip Morris International, British American Tobacco, Japan Tobacco International and Imperial Tobacco. ${ }^{3}$ Consequently, the cigarette trade is dominated in virtually all major markets by a very small, and declining, number of cigarette manufacturing companies (table 1). In 2008, for example, notwithstanding the publicly owned Chinese National Tobacco Company which has a $98 \%$ share of the Chinese market, the leading 
company in each of the world's largest cigarette markets had a market share of between $28 \%$ and $86 \%$ (table 1). The most striking indication of the highly concentrated nature of cigarette sales is the three-firm concentration ratio-the total market share in each country accounted for by the three companies with the largest market share. With the exception of Indonesia, in all the major markets just three firms control at least $80 \%$ of the market, and in many markets the top three firms account for more than $90 \%$ (table 1). To put such figures into perspective, the UK Competition Commission investigates mergers between companies that would result in firms gaining more than $25 \%$ market share or less where it appears likely there would be a substantial lessening of competition. ${ }^{4}$

This highly concentrated nature of cigarette markets is exacerbated by the significant underlying barriers to market entry by new cigarette manufacturers which have inadvertently been amplified by tobacco control measures, notably bans on advertising and promotion. ${ }^{5}$ These measures are essential and effective components of tobacco control strategies ${ }^{6}$ and are thus likely to expand in both scope and geographical reach. In addition, the product is highly addictive and there are no real alternatives, whether in the form of pharmaceutical nicotine or alternative tobacco products, currently available and able to compete with cigarettes.

This market failure gives cigarette companies immense pricing power which in turn is exacerbated by tobacco tax policies, the most effective tobacco control policy available. ${ }^{6}$ Taxes make up a large portion, and manufacturer's revenue a small portion, of the final price consumers pay. As a result, small increments in the manufacturer's margin have negligible impact on demand but equate to big increases in manufacturer revenue. This is particularly true in countries which have high specific tax levels. As normal competitive forces are absent, the resulting oligopoly can raise prices seemingly at will, generating sustained high profits, significantly higher than those earned on other consumer staples. ${ }^{7}$ As table 2 shows, the profitability of Europe's two largest tobacco companies (measured using the EBITA Margin - the firms' earnings before interest, taxation and amortisation expenses have been deducted as a proportion of its total revenue) is significantly greater than that of comparable consumer staple companies. Currently, tobacco profits are approximately double those of most other companies and these very high returns are predicted to continue into the future. Only one firm, Diageo, comes close to matching the high profitability of the tobacco companies; Diageo stands out as being abnormally profitable in the beverages industry sector and may also benefit from market power, reportedly enjoying $50 \%$ of the UK gin and $40 \%$ of the global vodka market. $^{8}$

These excess returns, through reinvestment in brand marketing, then further raise the barriers to market entry. In short, the immense profits cigarette companies make from selling a product that kills one in two of its users ${ }^{9}$ is not because of some breakthrough intellectual property or other typical marketplace advantage. Rather, it is a classic example of market failure.

How increases in specific taxes can benefit tobacco companies Ironically, this situation has been made worse by government cigarette excise policies in two main ways. First, in many

Table 1 Cigarette market shares (\%) by global brand owner for the major cigarette markets*, 2008

\begin{tabular}{|c|c|c|c|c|c|c|c|c|c|c|c|}
\hline Company & Brazil & Canada & China & Germany & India & Indonesia & Italy & Japan & Russia & UK & USA \\
\hline Philip Morris International Inc & 9.7 & 21.3 & 0.1 & 36.2 & 12.1 & 22.6 & 52.9 & 24.4 & 25.4 & 6.3 & \\
\hline British American Tobacco Plc & 86.3 & 59.0 & 0.6 & 20.0 & & 2.7 & 24.1 & 10.2 & 19.6 & 8.1 & \\
\hline Japan Tobacco Group Plc & & 10.8 & 0.2 & 5.0 & 1.3 & & 16.2 & 64.9 & 36.9 & 38.8 & 0.4 \\
\hline China National Tobacco Corp & & & 98 & & & & & & & & \\
\hline ITC Group† & & & & & 58.3 & & & & & & \\
\hline Golden Tobacco Ltd & & & & & 10.9 & & & & & & \\
\hline Gudang Garam Tbk PT & & & & & & 28.3 & & & & & \\
\hline Djarum PT & & & & & & 13.8 & & & & & \\
\hline Bentoel Internasional Investama Tbk PT & & & & & & 5.9 & & & & & \\
\hline Nojorono Tobacco Indonesia PT & & & & & & 5.5 & & & & & \\
\hline Société Industrielle des Tabacs du Cameron SA & 1.4 & & & & & & & & & & \\
\hline Donskoi Tabak OAO & & & & & & & & & 3.7 & & \\
\hline Private label & & & & 9.9 & & & & & & 1.7 & \\
\hline Others & 2.6 & 8.9 & 1.2 & 3.3 & 7.8 & 21.2 & 4 & 0.5 & 5.2 & 1.3 & 8.8 \\
\hline Total & 100 & 100 & 100 & 100 & 100 & 100 & 100 & 100 & 100 & 100 & 100 \\
\hline No. of companies with market share $>10 \%$ & 1 & 3 & 1 & 3 & 3 & 3 & 3 & 3 & 3 & 2 & 3 \\
\hline No. of companies with market share $>25 \%$ & 1 & 1 & 1 & 2 & 1 & 1 & 1 & 1 & 2 & 2 & 2 \\
\hline $\begin{array}{l}\text { Three-firm concentration ratio (cumulative share of } \\
\text { market of three biggest companies by market share) }\end{array}$ & 97.4 & 91.1 & 98.8 & 81.8 & 81.3 & 64.7 & 93.2 & 99.5 & 81.9 & 90.8 & 85 \\
\hline
\end{tabular}

Euromonitor from trade sources/national statistics. Data obtained: 23 September 2009.

Note: Where companies other than those listed have a market share of $1 \%$ or less, their share has been added to the 'Others' category.

*Data given for the world's largest cigarette markets (China, Russia, US, Japan, Indonesia, Ukraine, Brazil, India), plus the two largest European markets (Italy and Germany) and the UK.

†Part owned by British American Tobacco.

$\ddagger$ Part owned by Philip Morris International. 
Table 2 Profitability (measured using the EBITA margin (\%)) for Europe's two major tobacco companies and comparator European consumer staple companies

\begin{tabular}{|c|c|c|c|c|c|c|c|c|}
\hline Company & 2004 & 2005 & 2006 & 2007 & 2008* & 2009* & 2010* & $2011^{*}$ \\
\hline \multicolumn{9}{|l|}{ Tobacco companies } \\
\hline British American Tobacco & 24.0 & 28.1 & 28.7 & 30.0 & 30.7 & 31.1 & 32.1 & 33.7 \\
\hline Imperial Tobacco Group & 40.2 & 41.5 & 42.9 & 45.0 & 28.2 & 37.7 & 39.4 & 39.5 \\
\hline \multicolumn{9}{|l|}{ Food companies } \\
\hline Cadbury & 15.6 & 15.9 & 14.4 & 13.5 & 12.0 & 13.0 & 13.8 & 14.9 \\
\hline Danone & 12.7 & 13.1 & 13.3 & 12.1 & 14.4 & 16.9 & 15.7 & 15.9 \\
\hline Nestle & 12.7 & 12.9 & 13.5 & 14.0 & 14.3 & 14.4 & 13.0 & 13.2 \\
\hline Premier Foods & 12.9 & 13.7 & 13.8 & 12.5 & 11.9 & 12.0 & 11.9 & 11.7 \\
\hline \multicolumn{9}{|l|}{ Consumer products companies } \\
\hline Unilever NV & 15.5 & 14.8 & 14.3 & 14.5 & 14.6 & 14.7 & 14.9 & 15.1 \\
\hline Henkel & 9.4 & 9.7 & 10.2 & 10.5 & 10.3 & 9.0 & 10.6 & 11.6 \\
\hline L'Oreal & 15.3 & 15.6 & 16.4 & 16.6 & 15.5 & 14.3 & 14.9 & 15.5 \\
\hline Reckitt Benckiser & 19.3 & 20.1 & 21.5 & 22.6 & 23.4 & 23.9 & 23.2 & 23.6 \\
\hline \multicolumn{9}{|l|}{ Beverage companies } \\
\hline Heineken NV & 13.6 & 13.1 & 13.0 & 14.8 & 13.2 & 13.5 & 14.0 & 14.4 \\
\hline SABMiller & 18.1 & 20.2 & 16.9 & 16.8 & 16.6 & 16.8 & 17.3 & 18.5 \\
\hline Carlsberg & 8.8 & 8.7 & 9.6 & 11.5 & 13.2 & 16.0 & 16.3 & 17.1 \\
\hline Diageo & 28.7 & 29.0 & 28.2 & 28.3 & 28.5 & 28.9 & 31.5 & 31.8 \\
\hline
\end{tabular}

Various Citigroup 'Consumer Central' business analyst investment reports.

*Estimated values

markets, particularly high tax markets where specific taxes predominate, cigarette companies are using tax rises to disguise price increases. This raises an issue, as reported in recent years by city analysts, that small, gradual tax increases, even at high rates of tax, may benefit the industry (in contrast to large intermittent tax increases) while having relatively little impact on consumption. ${ }^{7} 1011$ Some even suggest that the major transnationals now support higher specific taxes, albeit implemented gradually. ${ }^{12}$ As a result, high tax countries such as the UK, for example, are now often the industry's most profitable. ${ }^{11}$ It also partly explains why industry profits are increasing in most western markets despite declining cigarette sales. ${ }^{13}$ Second, this emphasis on specific taxes has further reduced competition in the market. Specific taxes tend to reduce price differentials while ad valorem taxes widen them making it harder for cheap brands to remain competitive (box 1). Specific taxes therefore tend to favour the major tobacco companies (which sell predominantly expensive cigarette brands or have a wide brand folio covering all price segments) over smaller companies mainly selling cheaper brands, and have probably contributed to the former's growing predominance.

This situation benefits the tobacco industry while disadvantaging the consumer, and reducing potential benefits to population health and the public purse. The extreme profitability of cigarettes gives tobacco companies both the incentive and the resources to fight public health measures designed to reduce tobacco consumption, and an enormous interest in opposing anything that could disrupt the current cigarette-dominated nicotine market. The pricing power of these companies also creates significant economic rents for the tobacco companies which ought to be captured by the state and used for wider social benefits.

\section{CHANGE IS NEEDED: WHAT ARE THE OPTIONS?}

There are three main approaches through which this particular market failure and related problems can be addressed, and any organisation charged with preventing market abuses would wish to consider each. First, creating more competition in the market; second, nationalising tobacco companies; and, third, regulating to overcome the negative consequences of market failure. The first would be both undesirable (as increased competition in the cigarette market would have negative public health consequences) and largely impossible given the existing barriers to market entry, which, as outlined above, will increase as tobacco control measures progress. Thus attempts to dismantle dominant cigarette companies or encourage new entrants to the cigarette market would almost certainly fail. The only way in which competition could potentially be increased is if a broader market in nicotine products could be created wherein smokeless tobacco and other nicotine products could compete with cigarettes. This too might raise public health concerns and, even if it were achievable, competition would be severely limited because the major cigarette manufacturers have now acquired virtually all the large independent smokeless tobacco manufacturers, ${ }^{15}$ and at least some, recognising cigarettes as their most profitable product, lack incentive to promote smokeless tobacco to compete with cigarettes while having every incentive to promote dual use in a way that maintains the cigarette market.

Nationalisation of transnational companies would capture the excess rent accruing to the industry for governments, but would be impractical, given the large revenues governments would need to buy out the companies, the difficulty of engendering public support and, in the case of transnational corporations, the complex legal challenges. Closely related proposals to remove the profit incentive from tobacco manufacturing by buying out the tobacco companies and transferring the assets to a not-forprofit organisation with a public health mandate would face similar problems.

Regulation to overcome the problems of market failure, therefore, seems a more attractive and practical proposal, and we propose below a system of price cap regulation. However, we first note that implementation of sufficient tobacco control regulations, with plain packaging being a key example, ${ }^{16} 17$ might also limit profitability. The impact of such policies on profits would, however, be far less certain than price cap regulation, particularly given the industry's well-documented history of circumventing previous advertising restrictions, ${ }^{18-20}$ and less immediate. Nor would other regulations raise money for the treasury. The key issue, however, is that one would not preclude the other: price cap regulation would make it easier to implement other tobacco control policies such as plain packaging because arguments about their negative impact on industry revenue would no longer apply and if such policies did adequately address the excess returns, then price regulation could stop.

\section{A PROPOSAL FOR CHANGE: PRICE CAP REGULATION}

We propose that the problems outlined above can be most easily addressed by the application of a system of price cap regulation, such as RPI-X, ${ }^{21}$ to tobacco products wherein the cap is applied to the manufacturers' pre-tax price but not the retail price. The rationale would be threefold. First, to help address the market failure described above and control the excessive margins enjoyed by the industry (without having to weaken essential tobacco control policies). Second, to increase government revenue by restricting the price the industry can charge, thus enabling governments to increase taxes and transferring rent from the tobacco industry to the government. Third, to bring public health benefits though a number of means outlined further in the next section.

To our knowledge only one previous (unsuccessful) proposal has been made to regulate manufacturers' prices, in British Columbia, Canada, in $1998 .^{23}$ Rules on minimum retail prices 


\section{Box 1 Ad valorem and specific taxes}

\begin{tabular}{|c|c|c|c|c|}
\hline $\begin{array}{l}\text { Ad valorem tax: } \\
\text { a percentage of } \\
\text { the retail price }\end{array}$ & \multicolumn{4}{|c|}{$\begin{array}{l}\text { Tends to widen price differentials by making expensive brands relatively } \\
\text { more expensive. Offers governments the advantage that tax is automatically } \\
\text { increased with industry price rises. Allows industry the advantage of } \\
\text { controlling the tax level by keeping its prices low (industry can lower its } \\
\text { prices in response to a tax increase, and prevent any public health benefit). } \\
\text { Not generally favoured by the large transnational companies that tend to sell } \\
\text { expensive brands. }\end{array}$} \\
\hline $\begin{array}{l}\text { Specific tax: a } \\
\text { fixed tax per } \\
\text { cigarette }\end{array}$ & \multirow{2}{*}{\multicolumn{4}{|c|}{$\begin{array}{l}\text { Reduces price differentials by adding a fixed tax to every cigarette regardles } \\
\text { of its baseline price, thus benefiting more expensive cigarettes and leading to } \\
\text { cheaper brands possibly being withdrawn from the market. Offers industry } \\
\text { the advantage of raising its base price and profit without increasing the tax, } \\
\text { and governments the advantage of being able to substantially raise price and } \\
\text { tax revenue by a known amount; therefore, generally favoured for tobacco } \\
\text { control. } \\
\text { Specific taxes are generally also favoured by the large transnational } \\
\text { companies that have expensive brands. } \\
\text { If we take two brands, one cheap ( } £ 3) \text { and one expensive }(£ 10) \text {, an ad } \\
\text { valorem tax of } 50 \% \text { would give prices of } £ 4.50 \text { and } £ 15.00 \text {, respectively, anc } \\
\text { lead to a price difference of } £ 10.50 \text {. A specific tax of } £ 5.00 \text { would lead to } \\
\text { prices of } £ 8.00 \text { and } £ 15.00 \text {, respectively, and a price difference of } £ 7.00 \text {, the } \\
\text { same as that before the taxes were applied. }\end{array}$}} \\
\hline \multirow[t]{5}{*}{ Example } & & & & \\
\hline & & Baseline & Plus ad valorem tax $(50 \%)$ & Plus specific tax (£5.00) \\
\hline & Cheap brand & $£ 3$ & $£ 4.50$ & $£ 8.00$ \\
\hline & Expensive brand & $£ 10$ & $£ 15.00$ & $£ 15.00$ \\
\hline & Price differential & $£ 7.00$ & $£ 10.50$ & $£ 7.00$ \\
\hline
\end{tabular}

Source: Adapted from Gilmore et al. ${ }^{14}$ Note: Many countries, including the countries of the European Union, have a mix of specific and ad valorem taxes.

are more widely known ${ }^{24}$ but differ significantly by focusing on retail rather than manufacturers' prices and fail to deal with the market failure and profit issue. Furthermore, a new (albeit contested) ruling suggests that minimum prices, in some instances at least, may be illegal under EU law. ${ }^{25}$

\section{PRICE CAP REGULATION: THE BASIC MODEL AND ITS APPLICATION IN THE UK}

Price cap regulation has been heavily utilised in the British utilities sector (and elsewhere) as a means of protecting society from the monopoly power of companies which face little or no competition given the nature of the market in question. ${ }^{21} 22$ As such, there are significant parallels to the tobacco industry where a strong case exists for further action to protect society from the effects of market failure. As this market failure applies to cigarette manufacturers rather than retailers, we envisage the system only applying to those manufacturing (rather than retailing) cigarettes for the UK market.

The system works by establishing an independent regulatory agency-The Office for Smoked Tobacco Regulation (OFSMOKE), for example-which would carry out periodic reviews of what cigarette companies are allowed to charge, setting maximum prices allowed for each product. The prices set would be based on how prices in the economy have generally changed (the retail price index (RPI) element), an assessment of the genuine costs each firm faces in its production and operations and an assumption about the productivity improvements it would be expected to make (the X element).
For the sake of simplicity, we can illustrate this solution by imagining how the system might work in practice. Let us assume that after some research on the industry's current costs the regulator sets the maximum price a manufacturer can charge, before any taxes or retailer's margin are added. This manufacturer's price would undoubtedly be less than the industry would wish to charge, thus curtailing profits. How much less would be judged by the regulator based upon its assessment of the legitimate costs the industry faces. This is illustrated in table 3 using a hypothetical example: the regulator caps the manufacturer's price at 50 pence per pack of 20 cigarettes, a 40 pence reduction from the baseline situation. The retailers would then add their mark-up as at present such that their profits would therefore be unaffected and the government also adds its various taxes and duties. When implementing a policy of RPI-X type price controls, government would need to use tax policy to ensure that the final price the consumer pays does not fall. Again this is illustrated in table 3, where the

Table 3 Hypothetical example of RPI-X regulation as applied to a pack of 20 cigarettes in the UK market (prices in pounds sterling (£))

\begin{tabular}{llll}
\hline & $\begin{array}{l}\text { Current } \\
\text { situation }\end{array}$ & RPI-X & $\begin{array}{l}\text { RPI-X plus government } \\
\text { response (ie, tax increase) }\end{array}$ \\
\hline Taxes $^{*}$ & 4.2 & 4.2 & 4.6 \\
Retailer take $\dagger$ & 0.4 & 0.4 & 0.4 \\
Manufacturers take $\dagger$ & 0.9 & 0.5 & 0.5 \\
Retail price & 5.5 & 5.1 & 5.5
\end{tabular}

*Includes tobacco excise tax and VAT (sales tax).

†ncludes costs and profit. 
imposition of a 50 pence price cap would result in a 40 pence reduction in retail price unless the government increases taxes accordingly. This 40 pence per pack currently accruing to tobacco companies as a result of a market failure would thereby be transferred to the national treasury.

The regulator would also have to consider whether this regulated price should change during each of the years of the price control period (usually between 3 and 5 years). Any permitted changes would be based upon predicted changes in average prices in the economy, predicted changes in industry costs and efficiency savings the regulator feels the company can make. For example, if average prices were seen to increase by $3 \%$ per year, and companies were judged able to operate more efficiently (ie, by removing unnecessary spending while achieving the same outputs) to the tune of $1 \%$ per year, the regulator would allow the 50 pence to increase by $2 \%$ in each of the subsequent years of the price control period.

Furthermore, when the regulator considers its next periodic price review, it would act as above, but would also consider what happened in the past control period. If some companies had been able to generate efficiency savings of more than the $1 \%$ assumed, then these additional savings could be taken into account when setting the next price controls. Thus any efficiency gains in production are ultimately gained by society, since benefits to the company are limited to one price control period. Similarly, changes in the price of key inputs, for example, or changes in the marketplace can also be taken into consideration, and it is this periodic flexibility to look forwards as well as backwards which ensures that neither the industry nor society is stuck with an unsatisfactory situation.

Within the system described above, individual companies or brands operating within the market may be allocated different prices depending on the costs of inputs and manufacturing, but given that most cost differences reflect packaging and marketing spend, differences would probably be marginal.

The regulated companies still have an incentive to run their operations efficiently since it is the price they can charge that is regulated, not the profits they can make. Thus by avoiding unnecessary costs, the firms can boost the profits that accrue to shareholders in the short term. In contrast to the current situation, they cannot use price increases as a means of boosting revenue.

\section{OTHER POTENTIAL BENEFITS}

There are also major public health benefits of introducing RPI-X type price regulation. It would remove the possibility of previously documented collusive price fixing, ${ }^{26-29}$ since prices would now be set by the regulator rather than by the firms themselves. It could also limit the use of price as a marketing tool, ${ }^{30}$ since differences between companies/brands would simply be based on genuine costs of production rather than attempts to segment the market through price. By significantly reducing price differentials, it would prevent down-trading to cheaper brands, a trend which has increased in numerous markets in recent years. ${ }^{31-33}$ Moreover, if prices and taxes were applied to handrolled and other smoked tobacco products in a similar way as to cigarettes, as they should be, regulation could also be used to prevent down-trading to hand-rolled products. ${ }^{33} 34$

In order to set the price caps OFSMOKE would inevitably need to closely monitor the industry, and this could help highlight, and ultimately eliminate, other practices including youth marketing ${ }^{35}$ and cigarette smuggling. ${ }^{36}$ For example, if, despite marketing restrictions, companies continued to actively and inappropriately promote their products to youth, then promotional budgets could be given limited allowances during the price review process by identifying these activities as targets for the efficiency savings. This would have the added benefit of requiring companies to disclose their promotional activities as currently required in Canada, for example. ${ }^{37}$ Even if marketing spend was not specifically targeted in this way, the system would indirectly limit the industry's marketing budget by removing its ability to re-use its efficiency savings, which for some companies have been substantial in recent years. ${ }^{38}$ The system of regulation could also be structured to help address the problem of tobacco smuggling. For instance, the price controls established would be based solely upon legal sales, which would give the manufacturers a direct incentive to help combat smuggling since the production costs of illicit sales would be ineligible to be counted as a legitimate expense, and any revenue gained from smuggled products would be more readily identified. Furthermore, we might even imagine a regime that includes penalties triggered by smuggling rates: high smuggling and black market sales would result in lower future prices for legitimate sales by way of a penalty for undesirable actions (or the lack of desirable actions).

The scope of regulation is also potentially flexible. Governments could set the scope of price regulation fairly narrowly on cigarettes and other smoked tobacco products or, should the policy of harm reduction find favour, more broadly on all tobacco products, or all nicotine products including pharmaceuticals. Thus governments could use the system to help direct changes it desires.

While a narrow focus on price regulation could have the advantage of reducing the likelihood of regulatory capture by the industry, since such regulation is relatively straightforward and has a documented record of success in other areas, the regulatory remit could, over time, be expanded beyond price. This could occur in a number of directions to address, for example, product content, marketing, distribution, access and underage sales that the manufacturer and retailer, in varying degrees, could be held responsible for. Such increased remit would bring the system in line with proposals for more comprehensive tobacco market regulation that have previously been made ${ }^{39}$ and might have a number of advantages. First, it might allow for greater integration and consistency in tobacco policy. Second, by addressing price, access to and promotion of all nicotine products within one regulatory system, it could help address the current imbalance in the nicotine market in which the most harmful nicotine delivery products (cigarettes) are the most accessible and the least harmful (pharmaceutical products) the least accessible. ${ }^{40} 41$ The issue of underage sales is somewhat more complex as both the manufacturer and the retailer could be held responsible, but could also be addressed, at least in theory, if, for example, companies were held ineligible to profit from underage tobacco sales.

The most obvious benefit of RPI-X regulation, however, is the direct reduction in the tobacco industry's profit, because this will directly reduce the incentive and ability of tobacco companies to fight public health measures. Not only will the companies have fewer funds available to do this, but the industry would also be partially insulated against tobacco control measures and less able to argue that they would have negative economic impacts. When setting future price controls, OFSMOKE would take into account past and likely future changes to tobacco policy and if this included public health measures which would directly affect the industry, it would need to reflect the new constraints in the regulated prices the industry would be allowed to charge. Thus by removing some of the potential adverse affects on industry profitability, the system 
of RPI-X regulation would help reduce industry resistance to effective public health policy and would be a more practical means of doing so than previous proposals.

\section{PRACTICALITIES AND POTENTIAL POLICY CHALLENGES}

As with any significant change in policy, a number of issues would have to be considered when developing the regulatory system. The main and a potentially significant barrier would be reluctance to establish a regulatory agency. The issue of cost is, however, easily overcome because, as with other similar agencies, OFSMOKE could be funded through a levy or licence fee paid by all the tobacco companies operating in the market, and need not therefore cost the consumer or taxpayer directly. Consequently, it should be reasonably easy to sell the policy to consumers who are ultimately the voters behind the politicians who would have to implement such a scheme. Public mistrust of the tobacco industry is widely held even among smokers ${ }^{42}$ and thus a measure to control the oligopoly power of tobacco firms, given all the aforementioned benefits, should enjoy wide public support.

There are likely to be some, most notably the tobacco industry, who suggest that the imposition of this type of direct economic regulation is an extreme reaction. It is hard, however, to argue that nothing needs to be done given the extent of the market power and the number of deaths the sector causes. Moreover, potential alternatives, as outlined above, appear to be less practical or unlikely to address the market failure which will only be amplified by further tobacco control measures. Furthermore, the imposition of RPI-X regulation is in line with the UK Better Regulation Executive's five principles of sound regulation (box 2), thus eliminating a likely line of industry argument. $^{43}$

A further consideration is whether the tobacco industry or retailer would undermine price controls by switching to a low price strategy. While theoretically possible, both are unlikely. As the proposal would not alter profit margins for the retailer, there is no reason for them to change their current pricing behaviour. For the manufacturer, price controls would probably be set low enough to only allow a return that just covers the cost of industry capital. Thus cutting prices would severely restrict profit per unit. Other tobacco control measures, combined with the inelasticity of demand, would mean that manufacturers and retailers are most unlikely to be able to increase sales sufficiently to offset the reduction in revenue per pack that would result, suggesting this would not be a sensible strategy. Furthermore, even if they were to attempt to cut prices, the government could

Box 2 The principles of sound regulation and how they are met

Five principles for sound regulation are advocated by the UK Better Regulation Executive. The proposed system would meet these because:

- It is proportionate to the problem at hand

- The regulator would be accountable for its actions

- It is consistent with wider government policy towards the tobacco industry

- It is transparent as RPI-X is a well-known system with industry consultation and the right to appeal

- It is clearly targeted at the cause of the problem

Source: http://www.berr.gov.uk/whatwedo/bre/index.html respond by further increasing taxes to ensure the price the consumer faces does not fall.

Finally, some might suggest that the increased government revenue might reduce government incentives to implement effective tobacco control measures. While theoretically an issue, it is possible, given the price inelasticity of tobacco, that just as industry profits are increasing despite falling sales, government revenue might follow the same pattern. Even if this was not the case (and this would require further research), any perverse incentives would be mitigated by two aspects of price cap regulation. First, the industry would now have far less incentive to lobby heavily against tobacco control measures as outlined above. Second, the regulatory agency would help distance and shield government from the tobacco industry, as the regulator would now be responsible for determining the impact of tax and tobacco control policies on the industry.

Importantly, most governments have extensive experience in undertaking these sorts of activities and the fact that price cap regulation is used in other sectors provides sufficient evidence of its feasibility and legality under both World Trade Organization and European Union rules. Although a detailed review of these issues is outside the remit of this initial exploratory paper, we note that the cap would apply equally to domestic and imported products (and thus be compliant with Article III of the Global Agreement on Tariffs and Trade (GATT)), and as the system would allow reasonable profits (being intended to capture excess profits, not cut sales-the latter being addressed separately through excise policy), it could not be considered a 'quantitative restriction' (Article XI of GATT).

\section{THE POTENTIAL FOR BROAD APPLICATION}

We believe the system proposed could be applied to most markets and, given the consolidation in the tobacco industry in recent years and the highly concentrated market shares seen globally (table 1), ${ }^{3}$ is increasingly likely to be needed. There are also no reasons why such a scheme is not suitable for markets dominated by state-owned companies. Regulation of a dominant state run firm might seem difficult if, for example, the government in question relies upon it for revenue. However, as established above, regulation of industry prices gives greater scope for direct taxation of tobacco products, so any reduction in the dividends to the government could be offset through the greater scope that they gain in tax policy. Furthermore, there are precedents for dominant government-owned companies being made subject to independent RPI-X regulation, with the Royal Mail in the UK being an example. The key is that the regulation of prices is conducted by an independent regulator acting in the wider public interest, rather than the government making decisions in light of its political position. Moreover, as explored above, there is flexibility in how the system could be applied and it could therefore be carefully adapted to the national context.

\section{MOVING FORWARD}

Clearly such a proposal moves both tobacco pricing and regulation beyond its traditional boundaries and further work would be needed to examine in detail how such a scheme might be established. There is, however, a substantial literature and much documented success of adopting RPI-X regulation ${ }^{21} 22$ and we therefore believe this is a realistic and attractive policy option. This paper demonstrates the strong case for regulation, that the system can be simply applied at no cost to the taxpayer and would bring numerous potential health and fiscal benefits. We recognise that any new proposal is likely to meet with initial 


\section{What is already known}

Market failure in the form of market power is a serious problem in many tobacco markets.

- Market power has given cigarette manufacturers considerable pricing power and profits particularly in high income markets.

- These problems have been exaggerated by unintended consequences of tobacco control policies.

\section{What this paper adds}

This paper suggests that market failure, excess profits and public health objectives could be addressed using a system of price cap regulation wherein a cap is placed on the manufacturers' price but not on the retail price that consumers face.

- Such a system would increase government revenue by transferring the excess profits from the industry to the government purse.

- Public health benefits would be realised in a number of ways. First, the system would enable additional tobacco control measures to be implemented without further exaggerating the market failure. Second, the industry's ability to undermine public health measures by using its excess profits to market its products and lobby against tobacco control measures would be curtailed. Finally, it could offer a means of preventing down-trading to cheaper tobacco products and controlling other unwanted industry practices such as cigarette smuggling, price fixing and marketing to the young.

resistance, but hope that, if nothing else, this paper will have stimulated debate about anomalies in the current cigarette market that urgently need addressing.

Acknowledgements The authors would like to thank Cathy Flower for administrative support.

Funding This work was informed by work undertaken as part of the National Cancer Institute, US National Institutes of Health, grant number R01 CA91021 and the European Commission Framework Programme 7 project grant PPACTE, grant agreement number 223323. AG is supported by a Health Foundation Clinician Scientist Fellowship and is a member of the UK Centre for Tobacco Control Studies which receives core funding from the British Heart Foundation, Cancer Research UK, Economic and Social Research Council, Medical Research Council, and the Department of Health under the auspices of the UK Clinical Research Collaboration. The funders had no involvement in the study design, collection, analysis and interpretation of the data; the writing of the report; or the decision to submit the paper for publication.

Competing interests None.

Provenance and peer review Not commissioned; externally peer reviewed.

\section{REFERENCES}

. Sloman J, Hinde K. Economics for Business. 4th edn. Harlow, England: FT Prentice Hall, 2007.

2. Jha $\mathbf{P}$, Musgrove P, Chaloupka FJ. Chapter 7: The economic rationale for intervention in the tobacco market. Pages 153-74. In: Jha P, Chaloupka FJ, eds. Tobacco control in developing countries. Oxford: Oxford University Press, 2000.

3. Hedley D. Consolidation endgame in sight-but is there one more big throw of the dice? Euromonitor 2007. http://www.euromonitor.com/Consolidation_endgame_in sight but is there one more big throw of the dice.

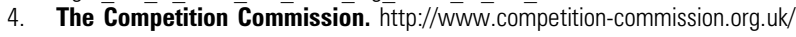
about_us/index.htm (accessed 22 Jan 2009).
5. Shepherd PL. Transnational Corporations and the International cigarette industry. In: Newfarmer RS, ed. Profits progress and poverty. Notre Dame: University of Notre Dame Press, 1985:63-112.

6. World Bank. Curbing the Epidemic - Governments and the Economics of Tobacco Control. Washington, DC. World Bank, 1999. http://www1.worldbank.org/tobacco/ book/html/cover2a.html.

7. Morgan Stanley. Tobacco-Late to the Party. London. Morgan Stanley Research Europe, 2007

8. Corporate Watch. Diageo plc, a corporate profile. http://www.corporatewatch.org. uk/?lid=1705 (accessed 25 Jan 2009).

9. Peto R, Lopez A, Boreham J, et al. Mortality from Smoking in Developed Countries 1950-2000: Indirect Estimates from National Vital Statistics. Oxford: Oxford University Press, 1994.

10. Gilmore A, Collin J, Cartwright $\mathrm{S}$, et al. Understanding the tobacco industry to plan for the future of tobacco control. 14th World Conference on Tobacco or Health. Mumbai 2009.

11. Citigroup Smith Barney. The Startling Business of Tobacco. Citigroup Smith Barney, 6 March 2008.

12. Morgan Stanley. British American tobacco plc. Meetings highlight "room for growth" and Americas strength. September 182009.

13. Euromonitor International. Global Tobacco: the Power of Cigarette Pricing Euromonitor International, 2009. http://www.euromonitor.com/Global Tobacco The Power of Cigarette Pricing (accessed 13 Sept 2010).

14. Gilmore A, Collin J, Townsend J. Transnational tobacco company influence on tax policy during privatization of a state monopoly: British Tobacco and Uzbekistan. Am J Public Health 2007:97:2001-9.

15. McNeill A, Sweanor D. Beneficence or Maleficence: big tobacco and smokeless products. Addiction 2009:104:167-8.

16. British American Tobacco. British American Tobacco Response to the Department of Health Discussion Document "Consultation on the Future of Tobacco Control, May 2008". 2008. http://www.bat.com/group/sites/uk 3mnfen.nsf/vwPagesWebLive/ D07J7CSX/\$FILE/medMD7J7CUJ.pdf?openelement (accessed 13 September 2010).

17. Imperial Tobacco Group PIc and Imperial Tobacco UK. Joint Submission to the Department of Health Consultation on the Future of Tobacco Control. 2008. http://www.imperial-tobacco.com/files/misc/uktobaccoconsultation_submission.pdf (accessed 11 Jul 2009).

18. Assunta M, Chapman S. "The world's most hostile environment": how the tobacco industry circumvented Singapore's advertising ban. Tob Control 2004;

13(suppl 2):iij1-7. http://tobaccocontrol.bmj.com/cgi/content/abstract/ 13/suppl_2/ii51.

19. Neuman $\mathbf{M}$, Bitton A, Glantz S. Tobacco industry strategies for influencing European Community tobacco advertising legislation. Lancet 2002;359:1323-30. http://www.ncbi.nlm.nih.gov/entrez/query.fcgi?cmd=Retrievegdb=PubMedgdopt= Citationglist uids $=11965294$

20. Gilmore A, Collin J, McKee M. British American Tobacco's erosion of health legislation in Uzbekistan. BMJ 2006;332:355-8.

21. Baldwin R, Cave M. Understanding Regulation: Theory, Strategy, and Practice. Oxford: Oxford University Press, 1999.

22. Bartle I. The UK Model of Utility Regulation. CRI Proceedings 31. University of Bath 2003. http://www.bath.ac.uk/cri/pubpdf/Conference seminar/

31 Model_Utility_Regulation.pdf (accessed 1 Sep 2009).

23. Government of British Columbia. TOBACCO FEE ACT. 1998/99 Legislative Session: 3rd Session, 36th Parliament, 29. http://www.leg.bc.ca/36th3rd/1st read/ gov29-1.htm (accessed 12 Jan 2010)

24. Chapman S, Freeman B. Regulating the tobacco retail environment: beyond reducing sales to minors Tob Control 2009;18:496-501.

25. Opinion of Advocate General. Case C-197/08, C-198108, C-221108. 2009. http://www.curia.europa.eu/ (accessed 27 Jan 2010)

26. Anon. "Tobacco Industry: the Price is not Quite Right". The Economist 2001.

27. Sibun J. "OFT's Hefty Fines for Tobacco Price Fixing". The Telegraph, 2009. http://www.telegraph.co.uk/finance/newsbysector/retailandconsumer/2793107/ OFTs-hefty-fines-for-tobacco-price-fixing.html (accessed 20 Sep).

28. Henry E. "OFT claims Supermarkets Fixed Cigarette Prices". The Telegraph, 2008. http://www.telegraph.co.uk/news/1903426/OFT-claims-supermarkets-fixedcigarette-prices.html (accessed 20 Sep).

29. Office of Fair Trading. "OFT Reaches Early Resolution Agreements in Tobacco Case". OFT Press, 2008. http://oft.gov.uk/news/press/2008/82-08 (accessed 19 Sep).

30. Moodie C, Hastings G. Making the pack the hero, tobacco industry response to marketing restrictions in the UK: findings from a long-term audit. Int J Ment Health Addict 2009. http://www.dx.doi.org/10.1007/s11469-009-9247-8.

31. Jarvis M. Supermarket cigarettes: the brands that dare not speak their name. BMJ 1998;316:929-31.

32. Imperial Tobacco Group PLC. Interim management statement. 2009 http://www.imperial-tobacco.com/index.asp?page $=78$ gnewsid $=685$ (accessed 29 Sep).

33. Euromonitor. "Cigarettes-United Kingdom". Euromonitor International Country Sector Briefing, 2009.

34. Brinson B. "AS the government hikes taxes on factory-made cigarettes, European smokers increasingly turn to do-it-yourself products". Tob Rep 2004. http://www.tobaccoreporter.com/home.php?id=119\&cid=4\&article $i d=10210$ (accessed 19 Sep 2009). 
35. Devlin E, Eadie D, K A. Tobacco Marketing and Young People. NHS Health Scotland, 2003. http://www.tobaccopapers.com/casestudies/Yth-Smoking.pdf.

36. House of Commons Committee of Public Accounts. Third Report: Tobacco Smuggling HC143. London. Houses of Parliament, 2003. http://www.publications. parliament.uk/pa/cm200203/cmselect/cmpubacc/143/14302.htm (accessed 29 Sep 2009).

37. Tobacco Act. Link to Health Canada's Reporting Requirements. http://www.hc-sc.gc.ca/hc-ps/tobac-tabac/legislation/reg/indust/index-eng.php (accessed 29 Sep 2009).

38. British American Tobacco. Annual report and accounts. 2007. http://www.bat.co. uk/group/sites/uk 3mnfen.nsf/vwPagesWebLive/D052AK34/\$FILE/ medMD7D9KKN.pdf?openelement (accessed 22 Sep 2009).
39. Borland R. A strategy for controlling the marketing of tobacco products: a regulated market model. Tob Control 2003;12:374-82.

40. Gilmore A, Britton J, Arnott D, et al. The place for harm reduction and product regulation in UK tobacco control policy. J Public Health 2008:31:3-10.

41. Tobacco Advisory Group of the Royal College of Physicians. Harm Reduction in Nicotine Addiction: Helping People Who Can't Quit. London: Royal College of Physicians of London, 2007.

42. Hammond D, Fong G, Zanna MP, et al. Tobacco denormalization and industry beliefs among smokers from four countries. Am J Prev Med 2006;31:225-32.

43. Better Regulation Commission. Five Principles of Good Regulation. The Cabinet Office. London. 2000. http://www.archive.cabinetoffice.gov.uk/brc/publications/ principlesentry.html (accessed 3 Sep 2009). 